Visit us - www.researchjournal.co.in $\square$ DOI : 10.15740/HAS/IRJAES/8.1/170-175

International Research Journal of Agricultural Economics and Statistics Volume 8 | Issue 1 | March, 2017 | 170-175 e ISSN-2231-6434

\title{
Research Paper Financial feasibility of investment in Broiler poultry units in Raigad district of Maharashtra
}

See end of the paper for authors' affiliations

Correspondence to : S.T. GORE

Shriram College of Agriculture Business Management, Paniv, SOLAPUR (M.S.) INDIA

Paper History :

Received : 15.01.2017;

Revised : 13.02 .2017

Accepted : 23.02.2017
AbSTRact : Per farm total cost of production was found highest on large poultry farm (Rs. 5232209) followed by the medium (Rs. 2636044) and small (Rs. 1395372) poultry farms. The cost of production per $\mathrm{kg}$ of live weight has inverse relation with the size of broiler farms. Per farm gross returns obtained from small, medium and large groups were Rs. 1590276, Rs. 3180338 and Rs. 6579208, respectively. However at the overall level it was Rs. 3327833. Out of which 98.08 per cent from sale of broiler, 1.67 per cent from sale of manure and 0.25 per cent from sale of empty gunny bags. The per farm and per bird cost benefit ratios at overall level was 1:1.22, whereas different size groups it was 1:1.14, 1:1.21 and 1:1.26 from small, medium and large groups, respectively. The financial feasibility analysis indicated positive net present value, benefit cost ratio has greater than one and internal rate of returns more than prevailing rate of interest in all size of broiler farms. This showed that the broiler poultry farming is profitable business in Raigad district.

Key Words : Cost, Return, Financial feasibility, NPV, BCR, PBP, IRR

How To Cite This Paper : Raut, S.D., Malave, D.B. and Gore, S.T. (2017). Financial feasibility of investment in Broiler poultry units in Raigad district of Maharashtra. Internat. Res. J. Agric. Eco. \& Stat., 8 (1) : 170-175, DOI : 10.15740/HAS/IRJAES/8.1/170-175. 